\title{
Origin and role of hepatic myofibroblasts in hepatocellular carcinoma
}

\author{
Betul Gok Yavuzi,2, Roberto Carmagnani Pestana², Yehia I. Abugabal2, Sunil \\ Krishnan ${ }^{3}$, Jian Chen ${ }^{4}$, Manal M. Hassan ${ }^{5}$, Robert A. Wolff ${ }^{2}$, Asif Rashid ${ }^{6}$, Hesham \\ M. Amin ${ }^{7,8}$ and Ahmed O. Kaseb ${ }^{2}$ \\ ${ }^{1}$ Department of Basic Oncology, Hacettepe University Cancer Institute, Ankara, Turkey \\ ${ }^{2}$ Department of Gastrointestinal Medical Oncology, The University of Texas MD Anderson Cancer Center, Houston, TX, USA \\ ${ }^{3}$ Department of Radiation Oncology, The University of Texas MD Anderson Cancer Center, Houston, TX, USA \\ ${ }^{4}$ Department of Gastroenterology, Hepatology, and Nutrition, The University of Texas MD Anderson Cancer Center, Houston, \\ TX, USA \\ ${ }^{5}$ Department of Epidemiology, The University of Texas MD Anderson Cancer Center, Houston, TX, USA \\ ${ }^{6}$ Department of Pathology, The University of Texas MD Anderson Cancer Center, Houston, TX, USA \\ ${ }^{7}$ Department of Hematopathology, The University of Texas MD Anderson Cancer Center, Houston, TX, USA \\ ${ }^{8}$ MD Anderson Cancer Center UTHealth Graduate School of Biomedical Sciences, Houston, TX, USA \\ Correspondence to: Ahmed O. Kaseb, email: akaseb@mdanderson.org \\ Hesham M. Amin, email: hamin@mdanderson.org
}

Keywords: hepatocellular carcinoma; stellate cells; myofibroblasts; liver fibrosis; immunotherapy

Received: September 02, $2019 \quad$ Accepted: March 03, $2020 \quad$ Published: March 31, 2020

Copyright: Yavuz et al. This is an open-access article distributed under the terms of the Creative Commons Attribution License 3.0 (CC BY 3.0), which permits unrestricted use, distribution, and reproduction in any medium, provided the original author and source are credited.

\section{ABSTRACT}

Hepatocellular carcinoma (HCC) is the most common primary liver cancer and is the second leading cause of cancer-related death worldwide. Fibrosis and cirrhosis are important risk factors for the development of HCC. Hepatic myofibroblasts are the cells responsible for extracellular matrix deposition, which is the hallmark of liver fibrosis. It is believed that myofibroblasts are predominantly derived from hepatic stellate cells (HSCs), also known as Ito cells. Nevertheless, depending on the nature of insult to the liver, it is thought that myofibroblasts may also originate from a variety of other cell types such as the portal fibroblasts (PFs), fibrocytes, hepatocytes, hepatic progenitor cells (HPCs), and mesothelial cells. Liver myofibroblasts are believed to transform into cancer-associated fibroblasts (CAFs) while HCC is developing. There is substantial evidence suggesting that activated HSCs (aHSCs)/cancer-associated fibroblasts (CAFs) may play an important role in HCC initiation and progression. In this paper, we aim to review current literature on cellular origins of myofibroblasts with a focus on hepatitis B virus (HBV)- and hepatitis C virus (HCV)-induced hepatic fibrosis. We also address the role of aHSCs/CAFs in HCC progression through the regulation of immune cells as well as mechanisms of evolvement of drug resistance.

\section{INTRODUCTION}

HCC is the most common primary liver cancer and is the second leading cause of cancer-related death worldwide [1]. Globally, the incidence of HCC is increasing, including in the United States, with chronic hepatitis $\mathrm{C}$ virus (HCV) and non-alcoholic steatohepatitis (NASH) are considered the most prevalent risk factors [2]. In addition, there are several other risk factors that predispose to HCC including heavy alcohol intake and certain metabolic diseases such as hemochromatosis and alpha-1-antitrypsin deficiency. Geographical variations in HCC etiology are best exemplified by the fact that the most common etiology of liver cirrhosis, a prominent pre$\mathrm{HCC}$ clinicopathological condition, is $\mathrm{HCV}$ in the United States and Egypt, in contrast to HBV in Asia and some other developing countries [3].

Fibrosis is characterized by abundant extracellular matrix deposition, especially collagen I, as a result of persistent inflammation and continuous injury to organs 
such as the liver, kidney, and lungs [4]. HCC is a special type of cancer because $80-90 \%$ of the cases develop in a background of advanced liver fibrosis and cirrhosis [5]. Liver cirrhosis is one of the most serious complications of chronic liver diseases, with $5-10 \%$ of patients with liver cirrhosis developing HCC within 5 years [5]. Notably, majority of HCC patients experience fibrosis and cirrhosis before cancer development in contrast to most other types of cancer where fibrosis typically occurs as a reactive process in response to the tumor [6].

Historically, fibrosis was considered an irreversible process until recently, where several animal studies have shown that reversal of fibrosis may occur when the liver insult is removed [7]. Furthermore, evolving clinical evidence also confirms regression of hepatic fibrosis when the triggering insult is ceased. For example, in patients with chronic HBV infection, long-term suppression of viral replication with tenofovir disoproxil fumarate resulted in regression of fibrosis and even cirrhosis [8]. In one study of 38 patients with $\mathrm{HCV}, 61$ months after sustained virologic response (SVR) following interferon and ribavirin, $61 \%$ of the responders had regression of cirrhosis and $89 \%$ demonstrated decreased liver collagen content [9]. Notably, although fibrosis reversal prevented patients from developing complications of hepatic cirrhosis, it did not eliminate the risk of HCC development in spite of reducing such risk [10,11]. Unlike viral hepatitis-driven liver fibrosis, studies showing clinical evidence of regression of fibrosis in patients with alcoholic or non-alcoholic liver disease are lacking [7].

\section{CELLULAR ORIGIN OF HEPATIC MYOFIBROBLASTS}

In a healthy liver, extracellular matrix turnover is precisely regulated by an intricate balancing act between a group of enzymes called matrix metalloproteinases (MMPs) in one side, and their inhibitors, tissue inhibitors of metalloproteinases (TIMPs) on the other side [12]. Upon damage of the liver due to chronic inflammation, the expression of TIMPs and collagens is upregulated in activated fibroblasts. This results in inhibition of MMPs and subsequent deposition of matrix proteins especially collagen type 1 , which subsequently causes up to a tenfold increase in fibrotic matrix [13].

The main cell type that is responsible for fibrosis development is the myofibroblast, which is absent in normal liver [14]. Myofibroblasts are characterized by the expression of $\alpha$-smooth muscle actin ( $\alpha$-SMA), collagen type I. Beginning at the earliest stages of hepatocellular carcinogenesis and coincident with the development of $\mathrm{HCC}$, the myofibroblasts transform into cancer-associated fibroblasts (CAFs) [6]. Despite the extensive studies in this field, the exact cellular origin of liver myofibroblasts is largely unknown. Depending on the nature of injury to the liver, the origin of liver myofibroblasts may vary considerably [15] (Table 1). In fact, there is a strong evidence that hepatic stellate cells (HSCs) constitute a major fibrogenic cell population that is responsible for liver fibrosis (Figure 1). It is essential to elucidate the cell of origin of myofibroblasts, the mechanisms and signaling pathways that contribute to transformation of myofibroblasts, and crosstalk with cancer cells that leads to progression of $\mathrm{HCC}$.

\section{Hepatic stellate cells}

HSCs are located in between the hepatocytes and the sinusoidal endothelial cells (space of Disse), and constitute about $10 \%$ of all resident liver cells [16]. In the normal liver, HSCs are characterized by a non-proliferative, quiescent phenotype. Vitamin A lipid droplets in their cytoplasm represent the most distinctive feature of quiescent HSCs and provide an easy way to isolate these cells by means of density gradient centrifugation and flow cytometry [17]. There are also other markers that help to distinguish HSCs from other hepatic cells: glial fibrillary acidic protein (GFAP), desmin, lecithin retinol acyltransferase (LRAT), platelet-derived growth factor receptor- $\beta$ (PDGFR $\beta$ ), and heart- and neural crest derivatives-expressed protein 2 (HAND2) [18].

HSCs are activated during chronic liver injury and, during this process, HSCs gradually lose their lipid droplets and become myofibroblasts as regard to their secretory and phenotypic profile [18]. Activated HSCs are considered a major source of collagen deposition in liver fibrosis [19]. According to a study in transgenic mice, 82$96 \%$ of myofibroblasts originated from HSCs independent of the type of liver injury [20, 21]. Thus, HSCs stand out as precursors to myofibroblasts and as a primary cellular target for preventing or treating liver fibrosis prior to $\mathrm{HCC}$ development [21].

Although no direct relationship between liver fibrosis and hepatocellular carcinogenesis has been conclusively established, there is substantial evidence suggesting that HSCs may play a role in HCC initiation and progression [6]. Myofibroblasts in HCC is widely thought to be originated from HSCs [6]. An important study by Zhou et al. has shown that HSCs are activated by HCC cell-derived exosomes in a concentrationdependent manner and they are transformed $\alpha$-SMA and FAP positive CAFs [22]. These activated HSCs further promote cancer progression by secreting angiogenic cytokines [22]. In another study, a 12-marker panel of CAFs in HCC has identified from the Cancer Genome Atlas (TCGA) database, which is associated with both pathological and clinical progressions of cancer [23]. To validate the panel, HSC cell line LX2 is cultured with conditioned medium of Huh7 HCC cell line and cultured LX2 cells show increased expression of 12 marker proteins in addition to typical CAFs markers, $\alpha$-SMA and FAP [23]. 
Table 1: Potential cellular origin of hepatic myofibroblasts

\begin{tabular}{|c|c|c|}
\hline Potential Cell Types & Potential Biomarkers & References \\
\hline \multirow{5}{*}{$\begin{array}{l}\text { Hepatic stellate cells } \\
\text { (HSCs) }\end{array}$} & - GFAP & {$[17,18]$} \\
\hline & - Desmin & \\
\hline & - LRAT & \\
\hline & - PDGFR $\beta$ & \\
\hline & - HAND2 & \\
\hline \multirow[t]{3}{*}{ Portal fibroblasts (PFs) } & - Elastin & {$[15,24]$} \\
\hline & - Thy-1 & \\
\hline & - NTPDase2 & \\
\hline \multirow[t]{2}{*}{ Hepatocytes } & - FSP-1 & {$[28,32]$} \\
\hline & - FAP & \\
\hline \multirow{2}{*}{$\begin{array}{l}\text { Hepatic progenitor cell } \\
\text { (HPCs) }\end{array}$} & - CD133 & {$[34,35]$} \\
\hline & $\cdot \mathrm{CK}-7$ & \\
\hline \multirow[t]{2}{*}{ Fibrocytes } & $\begin{array}{l}\text { - CD11b, CD34, CD45, CD54, CD80, CD86, CCR1, } \\
\text { CCR2, CCR5, CCR7, MHCII, Gr1, Ly6c }\end{array}$ & {$[36,38]$} \\
\hline & - Collagen type 1, Fibronectin, Vimentin & \\
\hline \multirow[t]{2}{*}{ Mesothelial cells (MCs) } & • GPM6 & {$[45,46]$} \\
\hline & - ITGA8 & \\
\hline
\end{tabular}

Abbreviations: GFAP: glial fibrillary acidic protein. LRAT: lecithin retinol acyltransferase. PDGFR $\beta$ : platelet-derived growth factor receptor- $\beta$. HAND2: heart- and neural crest derivatives-expressed protein 2. NTPDase2: Ectonucleoside Triphosphate Diphosphohydrolase 2. FSP-1: fibroblast specific protein-1. FAP: Fibroblast Activation Protein Alpha. CK-7: Type II Cytoskeletal 7. MHC II: Major Histocompatibility Complex, Class II. GPM6: Glycoprotein M6. ITGA8: integrin $\alpha 8$.

\section{Portal fibroblasts (PFs)}

PFs are quiescent spindle-shaped fibroblasts that are located in the peri-portal space. Because of the paucity of markers identifying PFs, it is hard to distinguish these cells from other mesenchymal cells [15]. Elastin, Thy-1, and NTPDase2 are classically seen on PFs but not on HSCs [24]. Whereas the contribution of activated PFs to liver fibrosis is important during early stages of cholestatic liver injury, it has been shown that activated HSCs constitute the major source of myofibroblasts during late stages of cholestatic liver injury and in hepatotoxic liver injury [20].

\section{Hepatocytes}

Epithelial-mesenchymal transition (EMT) is a process characterized by epithelial cells gaining motility and mesenchymal features [25]. EMT plays important roles in tumor cell invasion and metastasis [26]. In addition, EMT potentially plays a key role in fibrogenesis. This is best characterized in the fibrotic kidney where 36\% of interstitial fibroblasts originate from tubular epithelial cells via EMT [25, 27]. Interestingly, Zeisberg et al. have shown that hepatocytes may contribute to the population of FSP-1 (fibroblast specific protein-1)-positive cells by undergoing EMT in $\mathrm{CCl}_{4}$-induced liver fibrosis [28]. FSP1 is expressed not only in fibroblasts but also in leukocytes and other non-fibroblastic cell types [29]. Meanwhile, there are several lineage tracing animal studies that have shown strong evidence against this claim. For example, Taure et al. utilized triple transgenic mice to demonstrate that hepatocytes do not undergo EMT to transform to fibrotic myofibroblasts in vivo [30]. Similarly, another study indicated that EMT of cholangiocytes traced by genetic labeling does not contribute to hepatic fibrosis in mice [31].

Myofibroblasts in HCC may be originated from HCC cells undergoing EMT. Hypoxia induces increased expression FAP, which is a typical marker for CAFs, in HCC cells through HIF-1 $\alpha$ [32]. In another study, it is shown that TGF- $\beta$, which regulates EMT and fibroblast maturation, induces $\alpha$-SMA in HCC cells [33]. However, it is unclear that whether this phenotypical change in HCC cells is correlated with functional features of CAFs and further studies are needed to clarify this issue.

\section{Hepatic progenitor cell (HPCs)}

HPCs are bipotent progenitor cells that give rise to hepatocytes and cholangiocytes in response to liver injury 
[34]. In a recent study, Sekiya et al. have shown that HPCs isolated from mice injured liver can differentiate into myofibroblasts, as a third distinct cell type, in addition to hepatocyte and cholangiocyte differentiation. They also have proposed that HPCs can contribute to the formation of the premalignant niche by abundant production of myofibroblasts [35].

\section{Fibrocytes}

Fibrocytes are bone marrow-derived cells that express both hematopoietic (CD11b, CD34, CD45, CD54, CD80, CD86, CCR1, CCR2, CCR5, CCR7, MHCII, Gr1, and Ly6c) as well as mesenchymal (collagen type 1 , fibronectin, and vimentin) markers [36]. In response to TGF- $\beta$, fibrocytes differentiate into $\alpha$-SMA-positive myofibroblasts. This event is associated with decreased expression of hematopoietic markers [37]. After recruitment to the site of injury, fibrocytes differentiate into myofibroblasts [38].

Only a small number of fibrocytes can be detected in the peripheral blood from healthy individuals [39]. Nonetheless, the number of circulating fibrocytes is increased under pathological conditions such as pulmonary fibrosis, which suggests that circulating fibrocytes may serve as a biomarker of disease progression [39-41]. In contrast, studies based on genetic lineage tracing mouse models of liver fibrosis have shown that myofibroblasts are mostly derived from sources other than the bone marrow suggesting that the contribution of fibrocytes to liver fibrosis is negligible $[20,21]$.

\section{Mesothelial cells (MCs)}

MCs are simple squamous cells lining the surface of visceral organs and body cavities (peritoneum, pericardium, and pleura). They secrete lubricating fluid to decrease the friction during organ movement. MCs exhibit both epithelial and mesenchymal features [42]. Studies have shown that MCs can migrate into the liver and give rise to HSCs in mouse liver development [42, 43]. A recent study using a mouse model has demonstrated that Wilms tumor 1 (Wt-1) expressing MCs can give rise to HSCs and myofibroblasts during liver fibrosis via mesothelial-mesenchymal transition [44]. On the contrary, in a study based on the bile duct ligation mouse model, cells of injured liver tissue have been isolated by flow cytometric sorting for GPM6, a mesothelial cell marker, GPM6-positive cells did not express type 1 collagen mRNA, suggesting that mesothelial cells may

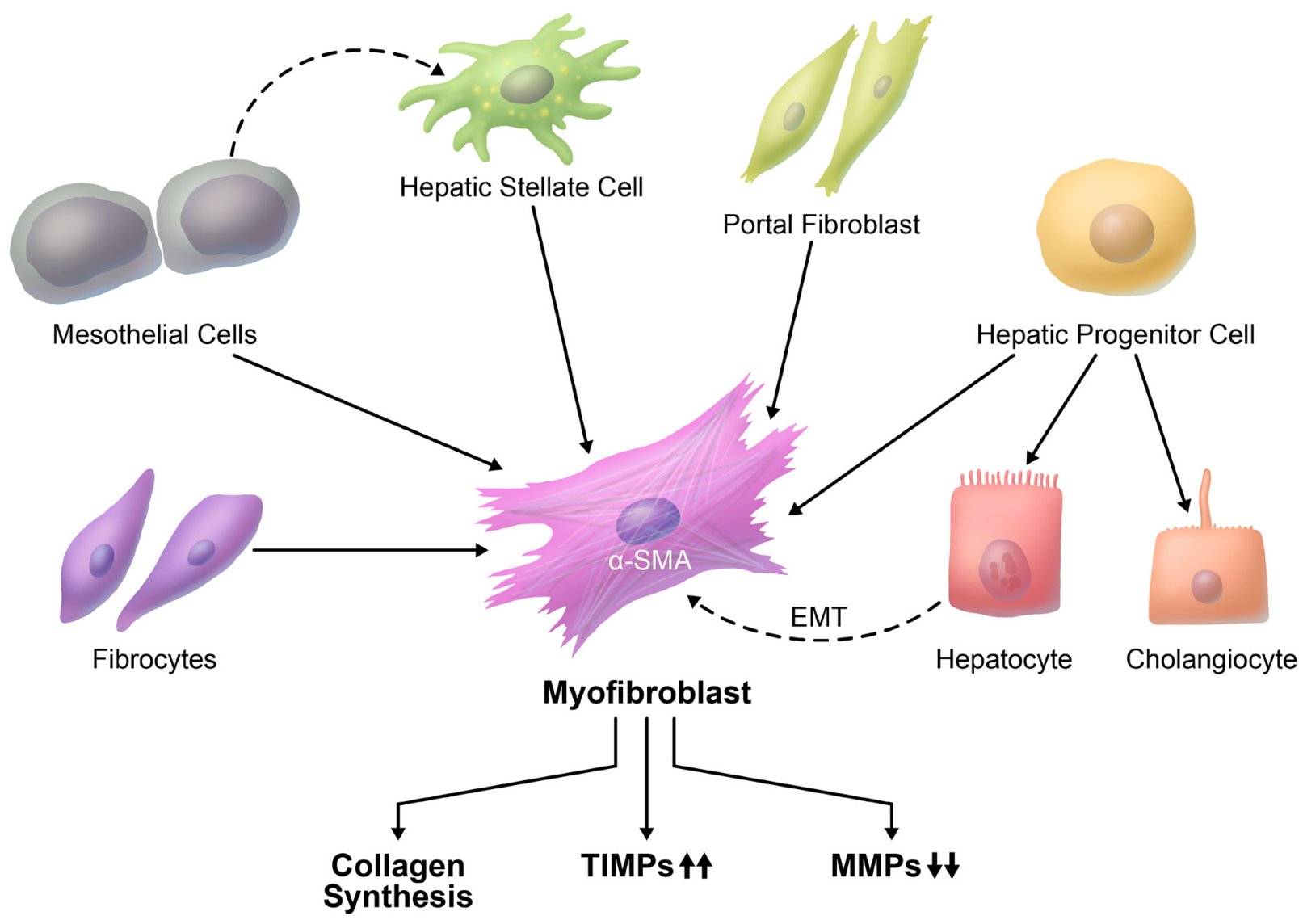

Figure 1: Cellular origin of liver fibrosis. There is more than one proposed origin of myofibroblasts in liver fibrosis. A major source of myofibroblasts is hepatic stellate cells. Myofibroblasts can also originate from portal fibroblasts, hepatic progenitor cells, mesothelial cells, and circulating fibrocytes. It is not clear whether myofibroblasts can be derived from hepatocytes through EMT (dashed line). 
not always transform into myofibroblasts during chronic liver injury [45]. Interestingly, a recent article reported that HSCs may show different gene expression profiles depending on their cell of origin [46]. In mice, the cell lineage tracing of $\mathrm{Wt}$-1-expressing $\mathrm{MCs}$ revealed that, upon differentiation from MCs, MC-derived HSCs lose the expression of MC markers and gain the expression of integrin $\alpha 8$ (ITGA8), making ITGA8 a unique cell surface marker for MC-derived HSCs in the developing liver [46]. Collectively, these data suggest that MCs may contribute to liver fibrosis indirectly through differentiation to HSCs. However, further studies are warranted to clarify the relative contribution of mesothelial cells to HSCs.

\section{PATHOPHYSIOLOGICAL MECHANISMS OF LIVER FIBROSIS}

Since HSCs are the main cell type contributing to liver fibrosis, most published literature is focused on HSC activation as the main triggering factor leading to liver fibrogenesis. The activation of HSCs encompasses a complex process that includes cellular and molecular interactions [18]. Briefly, initial liver injury by various etiologies such as viral hepatitis causes hepatocyte death resulting in inflammatory cell recruitment to the injury site. Thereafter, reactive oxygen species production and cytokine secretion (especially TGF- $\beta$ ) from inflammatory cells or hepatocytes activate specific intracellular pathways within HSCs. This leads to changes in HSCs behavior including stimulation of chemotaxis, proliferation, contractility, and ultimately fibrogenesis [47].

Different etiologies can induce liver fibrosis, but whether the course by which the fibrosis develops is modulated by etiology-specific factors, such as HBV vs. $\mathrm{HCV}$ is not clear, mainly because of the lack of pertinent animal models. In this review we specifically focus on the direct effects of $\mathrm{HCV}$ and $\mathrm{HBV}$ on liver fibrosis mostly based on in vitro experiments (Figure 2).

\section{HCV-mediated liver fibrosis}

$\mathrm{HCV}$ is a single-stranded RNA virus that can translate its polyprotein precursor in host cells. The precursor protein gives rise to structural (core, E1, E2, and p7) and non-structural (NS2, NS3, NS4A, NS4B, NS5A, and NS5B) proteins via proteolytic cleavage [48]. These proteins can act as key cellular regulators in an autocrine or paracrine manner [49]. In fact, core proteins can easily be detected in the serum of chronic HCV patients [50]. Core proteins of $\mathrm{HCV}$ can directly activate HSCs by interacting with $\mathrm{C} 1 \mathrm{q}$ to increase proliferation of HSCs. On the other hand, NS3 and NS5 can activate NF- $\kappa$ B and c-Jun N-terminal kinase pathways of HSCs and increase the expression of collagen-I in HSCs [51]. HCV envelope protein 2 (E2) can also increase the expression of MMP-2 in HSCs through E2/CD81 interaction [52].
$\mathrm{HCV}$ can directly infect human skin fibroblasts and induce the expression of pro-fibrotic proteins such as vimentin, collagen, and $\alpha$-SMA by activating GLI2 (glioma-associated oncogene family zinc finger 2), which has been previously linked to organ fibrosis $[53,54]$. Since HSCs are considerably different from skin fibroblasts [55], this finding should also be confirmed in HSCs.

Fibrocytes are another cell type that may contribute to $\mathrm{HCV}$-mediated liver fibrosis. Patients who are infected with HCV have higher levels of circulating fibrocytes in their peripheral blood than healthy people [56]. Although the exact mechanisms of fibrocyte-induced fibrosis in $\mathrm{HCV}$-infected patients is not fully understood, it has been recently shown that, during $\mathrm{HCV}$ infection, viral ssRNA differentiates monocytes to collagen-expressing fibrocytes via TLR 7/TLR 8 [57]. Further studies are needed to elucidate how these fibrocytes are recruited to the injury site and whether they may serve as a biomarker of disease progression like in patients with pulmonary fibrosis.

\section{HBV-mediated liver fibrosis}

The HBV has a partially double-stranded DNA encoding the $\mathrm{C}, \mathrm{S}$ and $\mathrm{X}$ proteins, reverse transcriptase, and polymerase [58]. Although the role of these viral proteins on tumor development has been extensively studied, their possible role on fibrogenesis is a relatively new subject in the literature. Bai et al., have shown that after co-culture with the cells expressing HBV C and $\mathrm{X}$ viral proteins or incubation with HBV particles, HSC cell line LX-2 cells proliferate and increase their expression of $\alpha$-SMA and collagen I $[59,60]$. Similarly, the expression of collagen I, $\alpha$-SMA, and TIMP-1 is increased in HSC-T6 cells (rat HSCs) after transfection of the hepatitis B envelope antigen (HBeAg) [61]. These effects are mediated by increased TGF- $\beta$ secretion in HSC-T6 cells and neutralization of TGF- $\beta$ can prevent their activation [61]. Unlike the HBV X and HBV C proteins, endogenous expression of $\mathrm{HBV}$ pre-core protein does not induce fibrogenic changes in HSCs [62].

\section{Macrophages in liver fibrosis}

Macrophages constitute the largest part of the non-parenchymal cellular compartment of the liver and important for liver fibrosis [63]. There are different types of macrophages in the liver in terms of origin and function: Tissue-resident macrophages, Kupffer cells (KC) or bone marrow-monocyte derived macrophages (MoMFs) [63]. KCs are particularly important during homeostasis such as iron metabolism and clearance of systemic pathogens, whereas MoMFs are recruited to the liver tissue when liver damage occurs and have an active role in liver inflammation [64].

KCs get activated following the liver injury and secrete many chemotactic stimuli (e. g. CCL2) for 
inflammatory cells. This results in the infiltration of a large number of MoMFs into the liver. These macrophages secrete pro-inflammatory cytokines and chemokines resulting in the activation of $\mathrm{HSCs}$ to fibrogenic phenotype [65].

Liver macrophages perform diverse functions in different stages of liver fibrosis. Impaired monocyte recruitment in liver results in reduced HSC activation and liver fibrosis $[65,66]$. However it is also shown that liver macrophages can exert fibrinolytic functions by secreting MMPs and anti-inflammatory cytokines especially at later stages of liver fibrogenesis [67, 68]. Liver macrophages show high plasticity that can change their phenotype and function according to stimulus they receive from their environment, which can explain their opposing functions in liver fibrogenesis [69].

As liver macrophages have important functions in liver fibrosis and are abundant in the liver, they have been seen as a potential target for treating liver fibrosis [70]. Potential strategies targeting macrophages include preventing the infiltration of monocytes, antagonizing the pro-inflammatory cytokines they secrete, modifying the functional activation status of macrophages to promote the liver fibrinolysis [71-73].

\section{ACTIVATED HSCS/CAFS, HCC DRUG RESISTANCE AND HCC IMMUNOTHERAPY}

Tumors are believed as "wounds that not heals" as chronic inflammation and fibrosis is generally precedes with tumor initiation. Several types of cells in the tumor microenvironment (immune cells, endothelial cells, and fibroblasts, etc.) support this process $[74,75]$. Fibrosis is particularly important for HCC development as 80-90\% of the cases develops in a background of advanced liver fibrosis and cirrhosis [5]. That's why, HSCs which are major fibrogenic cells in liver fibrosis are believed to transform into cancer associated fibroblasts in HCC and, CAFs are loosely defined as HSCs in HCC tissue $[6,22]$.

Activated HSCs signature is associated with earlier recurrence of $\mathrm{HCC}$ after resection [76]. HSCs may promote hepatocellular carcinogenesis in many ways [6]. For instance, activated HSCs induce angiogenesis and proliferation of tumor cells, as well as maintain the survival of tumor cells directly through mediators released from fibroblasts or indirectly via interactions with other cells. Herein, we specifically focus on the role of activated

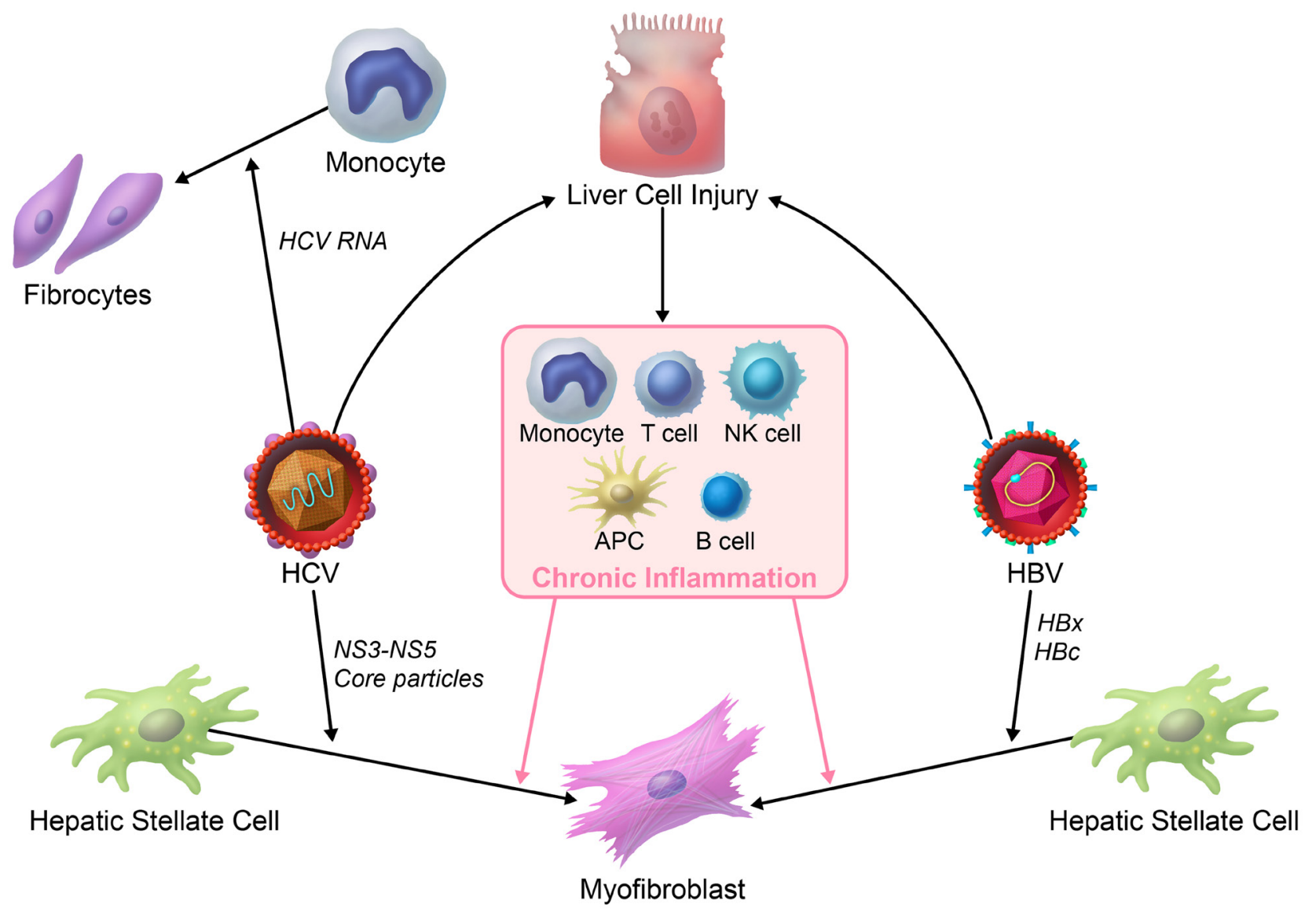

Figure 2: HBV-vs. HCV-induced liver fibrosis. HBV- or HCV-infected hepatocytes and/or inflammation activates hepatic stellate cells through soluble factors. There are some direct acting mechanisms that may lead to liver fibrosis in viral hepatitis. HCV virus can activate hepatic stellate cells by NS3-NS5 and core particles. It is also illustrated that HCV RNA can differentiate monocytes to fibrocytes. $\mathrm{HBV} \mathrm{HBx}$ and $\mathrm{HBc}$ particles are also believed to activate hepatic stellate cells. 
HSCs and CAFs on immunotherapy and drug resistance in $\mathrm{HCC}$, which are emerging subjects and not reviewed elsewhere.

There is a continuous crosstalk between stromal cells such as fibroblasts and immune cells in tumor microenvironment [77]. This crosstalk plays an important role in the development and progression of tumors [77]. Liver activated fibroblasts have recently gained significant interest for their potential function as regulators of immune cell recruitment and function (Figure 3).

A study by Zhao et al., has shown that HSCs inhibit T-cell proliferation. Co-transplantation of HSCs and H22 (murine hepatic cancer cell line) results in less immune cell infiltration in the tumor tissue, more regulatory $\mathrm{T}$ cells and myeloid derived suppressor cells (MDSCs) in the spleen and bone marrow, and more apoptotic mononuclear cells in the tumor tissue than transplantation of $\mathrm{H} 22$ cells alone in orthotopic liver tumor mouse models [78, 79].

Deng et al., have shown that tumor associated fibroblasts (TAFs) isolated from HCC tissues recruit monocytes via the stromal cell-derived factor (SDF)-1/ CXCR4 pathway and differentiate them into myeloidderived suppressor cells (MDSCs) through the IL-6/STAT3 axis. Furthermore, in human HCC tissue samples, CD11positive myeloid cells, which resemble TAF-educated monocytes are found to have a positive association with TAFs [80].

Regulatory dendritic cells (DCs) exhibit an immune suppressive phenotype by inhibiting T-cell proliferation through indoleamine 2,3-dioxygenase (IDO) production in tumor tissues [81]. Cheng et al., have shown that HCC-associated fibroblasts can recruit normal DCs and transform them to regulatory DCs through IL-6-mediated STAT3 activation. Moreover, inhibition of IL-6 and STAT3 can reverse this effect [82].

Natural killer (NK) cells are another important innate immune cell type that kill tumor cells. Fibroblasts isolated from human $\mathrm{HCC}$ tissue disrupt $\mathrm{NK}$ cell functions. NK cells co-cultured with HCC fibroblasts have shown decreased expression of cytotoxic molecules and

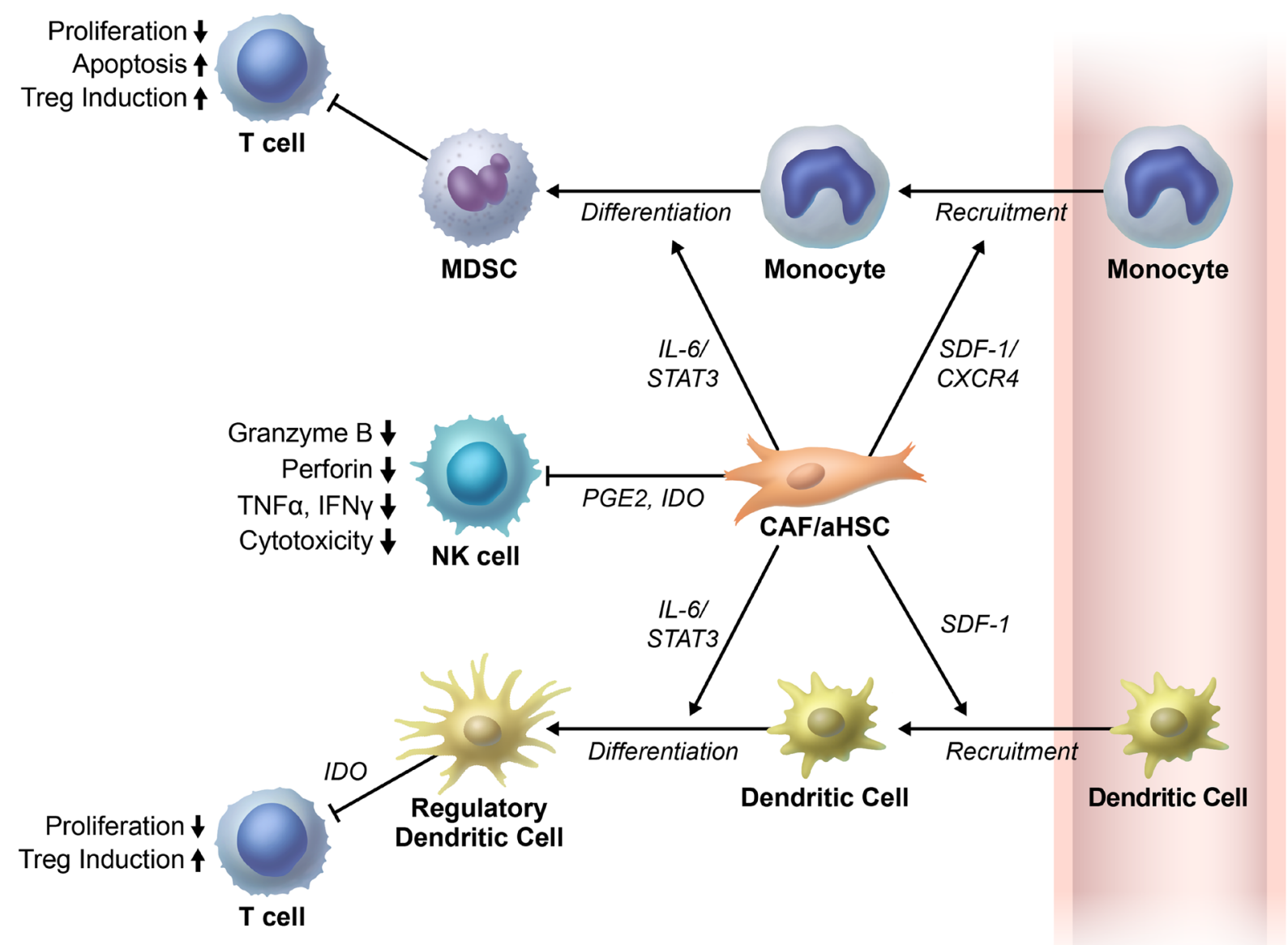

Figure 3: Cancer associated fibroblasts/activated hepatic stellate cells regulate immune cells in tumor microenvironment. Cancer associated fibroblasts/activated hepatic stellate cells (CAFs/aHSCs) inhibit T-cell proliferation directly (not shown in figure) or indirectly. They first recruit the monocytes and dendritic cells. Thereafter, CAFs/aHSCs differentiate the monocytes and dendritic cells to myeloid derived suppressor cells (MDSCs) and regulatory dendritic cells, respectively. Subsequently, these cells exhibit immunosuppressive functions in the tumor microenvironments. Moreover, the cancer associated fibroblasts (CAFs) in the liver impair NK cell functions. The NK cells play important roles in the anti-tumor immune response through prostaglandin E2 (PGE2) and indoleamine 2,3-dioxygenase (IDO). Abbreviations: SDF, stromal cell-derived factor. 
surface markers for cell activation through prostaglandin E2 (PGE2) and IDO [83]. HSCs-derived PGE2 has also been shown to play a role in MDSCs recruitment to the tumor tissues. Moreover, inhibition of HSCs-derived PGE2 results in inhibition of HSCs-induced MDSCs accumulation in tumor tissue and thus suppression of HCC growth [84].

Identification of oncogenic addiction pathways in different tumor types has led to revolutionary therapeutic approaches in many cancers, such as imatinib for treatment of chronic myeloid leukemia [85]. Unlike many other cancer types, HCC does not show an addiction to a specific survival pathway. Moreover, tumor microenvironment may modify the sensitivity of tumor cells to inhibition of oncogenic pathways in HCC [86]. Recent studies have shown that HSCs may play a role in drug resistance. The HSC cell line LX2 cocultured with the HCC cells Huh7, can induce sorafenib resistance in these cells through multiple survival pathways including $\mathrm{HGF} / \mathrm{c}-\mathrm{Met} / \mathrm{Akt}$ and JAK2/STAT3. The addition of S3I201 (phosphorylated-STAT3 inhibitor) to the co-culture medium enhances sorafenib-induced apoptosis [87]. In another study, HSCs secreted extracellular matrix proteins and HSCs conditioned medium decreased the effectiveness of sorafenib on HCC cells via restoration of FAK activity through abrogation of ubiquitination [88]. It has also been reported that HSCs in multicellular tumor spheroids (MCTS) exhibited pronounced resistance to sorafenib and cisplatin compared to other types of stromal cells. Moreover, the therapeutic efficacy of sorafenib is increased in MCTS by using losartan which suppresses collagen I synthesis by HSCs [89].

Interestingly, some recent studies challenge the idea that stromal cells merely exert pro-tumorigenic functions. For example, targeting CAFs in mouse models of pancreatic ductal adenocarcinoma enhances tumor growth instead of inhibiting it [90]. Similarly, increased expression of the orphan receptor endosialin (CD248) in HSCs is inversely correlated with tumor cell proliferation in human HCC tumors, suggesting that this protein may be a negative regulator of HCC progression [91]. Further studies are needed to further characterize the mechanisms of switching between pro-tumorigenic and anti-tumorigenic effects of HSCs.

\section{PROGNOSTIC AND DIAGNOSTIC CYTOKINE BIOMARKERS IN HCC PATIENTS WITH CHRONIC VIRAL HEPATITIS AND LIVER FIBROSIS}

Biomarkers found in serum, tissue or other body fluids are important tools for screening, prognosis, prediction, and monitoring response to therapy in cancer. $\alpha$-fetoprotein (AFP) is the most widely used diagnostic and prognostic serum biomarker in $\mathrm{HCC}$, but most small
HCC do not secrete AFP. In fact, AFP sensitivity drops to $25 \%$ if the tumor is smaller than $3 \mathrm{~cm}$ in diameter [92]. Therefore, new biomarkers are required to enhance routine HCC diagnostic and prognostic schemes and improve early detection. Furthermore, such new biomarkers are expected to lead to identifying more effective therapeutic options that will ultimately improve survival of HCC patients. Several serum or tissue biomarkers have been recently proposed. Alas, most of these biomarkers have not been widely accepted in daily clinical practice [93, 94].

Persisting chronic liver injury induces a continuous cycle of inflammation, regeneration and proliferation of hepatocytes that results in accumulation of pathophysiologic aberrancies that lead to fibrosis, cirrhosis, and HCC initiation, as discussed above in detail [95]. However, 20\% of patients with HBV develop HCC without evident cirrhosis [96]. This may be partly explained by the fact that HBV can integrate its own DNA into the host genome resulting in disruption of critical regulatory pathways and initiation of carcinogenesis [97, 98]. Unlike HBV, HCV (RNA virus) cannot integrate its own genome into the host DNA. Therefore, HCVinduced HCC mostly develops in the context of liver cirrhosis suggesting that an indirect pathway of chronic inflammation may have a role in the carcinogenesis process in $\mathrm{HCV}$-associated $\mathrm{HCC}$ [99].

Entrenched within this framework of viral infection and transformation of resident liver cells into fibrogenic cells and/or cells with genomic instability is an environment that is permissive for initiation and progression of HCC. A key component of this permissive environment is the crosstalk between resident cells, migratory cells, and freshly recruited cells that is mediated by cytokines, which are important molecules for cellular interactions and especially in mediating the immune response to alterations in integrity of the liver structure and physiology. Since inflammation is a major response to viral hepatitis and possibly fibrosis and HCC development, cytokines in the liver and in the blood maybe used as a biomarker for disease progression. For example, Hsia et al. showed that the serum levels of IL-6 and IL-10 are frequently elevated in patients with HCC [100]. In the same study, among patients with low AFP levels, increased IL-6 or IL-10 levels were significantly associated with the presence of HCC suggesting that these cytokines may be used as a tumor marker for patients with low AFP [100]. These cytokines have also ben related to liver fibrosis, interestingly, and their role in the diagnosis of the continuum from liver disease to HCC deserves further studies [101, 102]. Although extensive research is ongoing in this field, the knowledge about the use of cytokines as diagnostic and prognostic tumor biomarkers in HCC is limited. Considering the difference in the mechanisms by which HBV and HCV can cause HCC and fibrosis, serum levels of possible prognostic and diagnostic biomarkers in patients with HBV or HCV should be evaluated separately. 
Table 2: Potential cytokine biomarkers in HCC patients with chronic viral hepatitis

\begin{tabular}{|c|c|c|c|c|}
\hline Cytokine & Sample size & Regulation & Information & Reference \\
\hline \multicolumn{5}{|c|}{ HBV-related cytokines } \\
\hline \multirow[t]{2}{*}{ Resistin } & $n=33$ (HBV-HCC) & \multirow[t]{2}{*}{ up } & \multirow[t]{2}{*}{ Differentiate $\mathrm{HCC}$ from $\mathrm{CHB}$} & \multirow[t]{2}{*}{ [99] } \\
\hline & $n=120(\mathrm{CHB})$ & & & \\
\hline \multirow[t]{2}{*}{ IL-7 } & $n=33$ (HBV-HCC) & \multirow[t]{2}{*}{ down } & \multirow[t]{2}{*}{ Differentiate $\mathrm{HCC}$ from $\mathrm{CHB}$} & \multirow[t]{2}{*}{ [99] } \\
\hline & $n=120(\mathrm{CHB})$ & & & \\
\hline \multirow[t]{2}{*}{ IL-8 } & $n=33$ (HBV-HCC) & \multirow[t]{2}{*}{ up } & \multirow[t]{2}{*}{ Differentiate $\mathrm{HCC}$ from $\mathrm{CHB}$} & \multirow[t]{2}{*}{ [99] } \\
\hline & $n=120(\mathrm{CHB})$ & & & \\
\hline \multirow[t]{2}{*}{ MDC } & $n=43$ (HBV-HCC) & \multirow[t]{2}{*}{ down } & \multirow[t]{2}{*}{ Differentiate $\mathrm{HCC}$ from $\mathrm{CHB}$} & \multirow[t]{2}{*}[104]{} \\
\hline & $n=33(\mathrm{CHB})$ & & & \\
\hline \multirow[t]{2}{*}{$\operatorname{MSP} \alpha$} & $n=43$ (HBV-HCC) & \multirow[t]{2}{*}{ down } & \multirow[t]{2}{*}{ Differentiate $\mathrm{HCC}$ from $\mathrm{CHB}$} & \multirow[t]{2}{*}[104]{} \\
\hline & $n=33(\mathrm{CHB})$ & & & \\
\hline \multirow[t]{3}{*}{ IL-6 } & $n=153(\mathrm{HBV}-\mathrm{LC})$ & \multirow[t]{2}{*}{ up } & Differentiate HCC from HBV-LC & {$[105]$} \\
\hline & $n=148(\mathrm{HBV}-\mathrm{HCC})$ & & Differentiate $\mathrm{HCC}$ from $\mathrm{CHB}$ & \\
\hline & $n=37$ & up & Differentiate $\mathrm{HCC}$ from $\mathrm{CHB}$ & {$[106]$} \\
\hline HCV-relate & & & & \\
\hline TNF- $\alpha$ & $n=10(\mathrm{HCV}-\mathrm{HCC})$ & up & Differentiate $\mathrm{HCC}$ from $\mathrm{CHC}$ & {$[107]$} \\
\hline & $n=10(\mathrm{HCV})$ & & & \\
\hline MIG & $n=10(\mathrm{HCV}-\mathrm{HCC})$ & up & Differentiate $\mathrm{HCC}$ from $\mathrm{CHC}$ & {$[107]$} \\
\hline & $n=10(\mathrm{HCV})$ & & & \\
\hline TRAIL & $n=10(\mathrm{HCV}-\mathrm{HCC})$ & up & Differentiate $\mathrm{HCC}$ from $\mathrm{CHC}$ & {$[107]$} \\
\hline & $n=10(\mathrm{HCV})$ & & & \\
\hline APRIL & $n=10(\mathrm{HCV}-\mathrm{HCC})$ & up & Differentiate $\mathrm{HCC}$ from $\mathrm{CHC}$ & {$[107]$} \\
\hline & $n=10(\mathrm{HCV})$ & & & \\
\hline VEGF & $n=10(\mathrm{HCV}-\mathrm{HCC})$ & up & Differentiate $\mathrm{HCC}$ from $\mathrm{CHC}$ & {$[107]$} \\
\hline & $n=10(\mathrm{HCV})$ & & & \\
\hline IL-3 & $n=10(\mathrm{HCV}-\mathrm{HCC})$ & up & Differentiate $\mathrm{HCC}$ from $\mathrm{CHC}$ & {$[107]$} \\
\hline & $n=10(\mathrm{HCV})$ & & & \\
\hline TWEAK & $n=10(\mathrm{HCV}-\mathrm{HCC})$ & up & Differentiate $\mathrm{HCC}$ from $\mathrm{CHC}$ & {$[107]$} \\
\hline & $n=10(\mathrm{HCV})$ & & & \\
\hline $\mathrm{SCF}$ & $n=10(\mathrm{HCV}-\mathrm{HCC})$ & up & Differentiate $\mathrm{HCC}$ from $\mathrm{CHC}$ & {$[107]$} \\
\hline & $n=10(\mathrm{HCV})$ & & & \\
\hline IL-21 & $n=10(\mathrm{HCV}-\mathrm{HCC})$ & up & Differentiate $\mathrm{HCC}$ from $\mathrm{CHC}$ & {$[107]$} \\
\hline & $n=10(\mathrm{HCV})$ & & & \\
\hline FGF2 & $n=10(\mathrm{HCV}-\mathrm{HCC})$ & up & Differentiate $\mathrm{HCC}$ from $\mathrm{CHC}$ & {$[107]$} \\
\hline & $n=10(\mathrm{HCV})$ & & & \\
\hline GRO-alpha & $n=10(\mathrm{HCV}-\mathrm{HCC})$ & up & Differentiate $\mathrm{HCC}$ from $\mathrm{CHC}$ & {$[107]$} \\
\hline & $n=10(\mathrm{HCV})$ & & & \\
\hline Exotaxin-3 & $n=10(\mathrm{HCV}-\mathrm{HCC})$ & up & Differentiate $\mathrm{HCC}$ from $\mathrm{CHC}$ & {$[107]$} \\
\hline & $n=10(\mathrm{HCV})$ & & & \\
\hline IL-22 & $n=10(\mathrm{HCV}-\mathrm{HCC})$ & up & Differentiate $\mathrm{HCC}$ from $\mathrm{CHC}$ & {$[107]$} \\
\hline & $n=10(\mathrm{HCV})$ & & & \\
\hline TNF- $\alpha \mathrm{R} 2$ & $n=20(\mathrm{HCV}-\mathrm{HCC})$ & up & Differentiate HCC from HCV-LC & {$[108]$} \\
\hline & $n=28(\mathrm{HCV}-\mathrm{LC})$ & & Differentiate $\mathrm{HCC}$ from $\mathrm{CHC}$ & \\
\hline & $n=25(\mathrm{CHC})$ & & & \\
\hline IFN- $\gamma$ & $n=20(\mathrm{HCV}-\mathrm{HCC})$ & down & Differentiate HCC from HCV-LC & {$[108]$} \\
\hline & $n=28$ (HCV-LC) & & Differentiate $\mathrm{HCC}$ from $\mathrm{CHC}$ & \\
\hline & $n=25(\mathrm{CHC})$ & & & \\
\hline
\end{tabular}




\begin{tabular}{|c|c|c|c|c|}
\hline \multirow[t]{3}{*}{ IL-1 $\beta$} & $n=20(\mathrm{HCV}-\mathrm{HCC})$ & \multirow[t]{3}{*}{ up } & Differentiate HCC from HCV-LC & \multirow[t]{3}{*}{108} \\
\hline & $n=28(\mathrm{HCV}-\mathrm{LC})$ & & Differentiate $\mathrm{HCC}$ from $\mathrm{CHC}$ & \\
\hline & $n=25(\mathrm{CHC})$ & & & \\
\hline \multirow[t]{6}{*}{ IL-10 } & $n=20(\mathrm{HCV}-\mathrm{HCC})$ & \multirow[t]{3}{*}{ up } & Differentiate HCC from HCV-LC & \multirow[t]{3}{*}{108} \\
\hline & $n=28(\mathrm{HCV}-\mathrm{LC})$ & & Differentiate $\mathrm{HCC}$ from $\mathrm{CHC}$ & \\
\hline & $n=25(\mathrm{CHC})$ & & & \\
\hline & $n=20(\mathrm{HCV}-\mathrm{HCC})$ & \multirow[t]{3}{*}{ up } & Differentiate HCC from HCV-LC & \multirow[t]{3}{*}{109} \\
\hline & $n=20$ (HCV-LC) & & Differentiate $\mathrm{HCC}$ from $\mathrm{HCV}$ & \\
\hline & $n=20(\mathrm{HCV})$ & & & \\
\hline \multirow[t]{3}{*}{ IL-2 } & $n=20(\mathrm{HCV}-\mathrm{HCC})$ & \multirow[t]{3}{*}{ down } & Differentiate HCC from HCV-LC & \multirow[t]{3}{*}{108} \\
\hline & $n=28(\mathrm{HCV}-\mathrm{LC})$ & & Differentiate $\mathrm{HCC}$ from $\mathrm{CHC}$ & \\
\hline & $n=25(\mathrm{CHC})$ & & & \\
\hline \multirow[t]{7}{*}{ IL-6 } & $n=120$ & up & Differentiate $\mathrm{HCC}$ from $\mathrm{CHC}$ & {$[110]$} \\
\hline & $n=20(\mathrm{HCV}-\mathrm{HCC})$ & \multirow[t]{3}{*}{ up } & Differentiate HCC from HCV-LC & \multirow[t]{3}{*}{109} \\
\hline & $n=20(\mathrm{HCV}-\mathrm{LC})$ & & Differentiate $\mathrm{HCC}$ from $\mathrm{HCV}$ & \\
\hline & $n=20(\mathrm{HCV})$ & & & \\
\hline & $n=20(\mathrm{HCV}-\mathrm{HCC})$ & \multirow[t]{3}{*}{ up } & Differentiate HCC from HCV-LC & \multirow[t]{3}{*}[111]{} \\
\hline & $n=20(\mathrm{HCV}-\mathrm{LC})$ & & Differentiate $\mathrm{HCC}$ from $\mathrm{HCV}$ & \\
\hline & $n=20(\mathrm{HCV})$ & & & \\
\hline \multirow[t]{3}{*}{ IL-17 } & $n=20(\mathrm{HCV}-\mathrm{HCC})$ & \multirow[t]{3}{*}{ up } & Differentiate HCC from HCV-LC & \multirow[t]{3}{*}[111]{} \\
\hline & $n=20$ (HCV-LC) & & Differentiate $\mathrm{HCC}$ from $\mathrm{HCV}$ & \\
\hline & $n=20(\mathrm{HCV})$ & & & \\
\hline \multirow[t]{3}{*}{ sTNF-RII } & $n=30(\mathrm{HCV}-\mathrm{HCC})$ & \multirow[t]{3}{*}{ up } & Differentiate $\mathrm{HCC}$ from $\mathrm{CHC}$ & \multirow[t]{3}{*}[112]{} \\
\hline & $n=32(\mathrm{CHC})$ & & Differentiate HCC from CHC-PNALT & \\
\hline & $n=17$ (CHC-PNALT) & & & \\
\hline \multirow[t]{3}{*}{ sIL-2Ra } & $n=30(\mathrm{HCV}-\mathrm{HCC})$ & \multirow[t]{3}{*}{ up } & \multirow[t]{3}{*}{ Differentiate HCC from PNALT } & \multirow[t]{3}{*}[112]{} \\
\hline & $n=32(\mathrm{CHC})$ & & & \\
\hline & $n=17$ (CHC-PNALT) & & & \\
\hline \multirow[t]{3}{*}{ IL-8 } & $n=30(\mathrm{HCV}-\mathrm{HCC})$ & \multirow[t]{3}{*}{ up } & Differentiate $\mathrm{HCC}$ from $\mathrm{CHC}$ & \multirow[t]{3}{*}[112]{} \\
\hline & $n=32(\mathrm{CHC})$ & & Differentiate HCC from CHC-PNALT & \\
\hline & $n=17($ CHC-PNALT $)$ & & & \\
\hline
\end{tabular}

Abbreviations: CHB, chronic hepatitis B; CHC, chronic hepatitis C; HBV, hepatitis B virus; HCC, hepatocellular carcinoma; HCV, hepatitis C virus; LC, liver cirrhosis PNALT, persistent normal alanine aminotransferase.

Table 2 shows possible serum cytokine biomarkers that are differentially expressed in HCC patients compared to patients with chronic viral hepatitis stratified by HBV and HCV status.

\section{CONCLUSIONS}

This review provides a summary of recent literature on the pathogenesis of liver fibrosis that is often a prelude to HCC development in the setting of chronic viral hepatitis. A preponderance of studies suggest that HSCs are precursors to myofibroblasts, the cells responsible for ECM deposition that is the hallmark of fibrosis. Nevertheless, there are other possible routes to myofibroblast development and recruitment that implicate PFs, hepatocytes, fibrocytes, and MCs. It also appears that the exact cell of origin of HSCs is possibly being dictated by the nature of liver injury. Furthermore, the molecular signaling pathways that transform these cells,
HSCs in particular, into mediators of fibrogenesis are varied and highly context dependent. Convergence of multiple factors related to direct transformation of cells into cancer cells, paracrine effects of other stromal cells, and immune system alterations contribute to hepatocellular carcinogenesis and treatment resistance within the microenvironment of chronic liver injury. Relevant observations addressed in this review carry significant importance considering recent emergence of immune modulatory-based therapies as a legitimate approach to treat HCC [103].

\section{Abbreviations}

$\alpha$-SMA: alpha-smooth muscle actin; AFP: alpha fetoprotein; aHSC: activated hepatic stellate cells; CAFs: cancer associated fibroblasts; $\mathrm{CCl}_{4}$ : carbon tetrachloride; CHB: chronic hepatitis B; CHC: chronic hepatitis C; DC: dendritic cells; E2: envelope protein 2; ECM: extracellular 
matrix; EMT: epithelial-mesenchymal transition; FSP-1: fibroblast specific protein-1; GFAP: glial fibrillary acidic protein; GLI2: glioma-associated oncogene family zinc finger 2; HAND2: heart- and neural crest derivativesexpressed protein 2; $\mathrm{HBeAg}$ : hepatitis B envelope antigen; $\mathrm{HBV}$ : hepatitis B virus; HCC: hepatocellular carcinoma; $\mathrm{HCV}$ : hepatitis $\mathrm{C}$ virus; HPC: hepatic progenitor cell; IDO: indoleamine 2,3-dioxygenase; ITGA8: integrin $\alpha 8$; LC: Liver cirrhosis; LRAT: lecithin retinol acyltransferase; MC: mesothelial cell; MDSC: myeloid derived suppressor cells; MMP: matrix metalloproteinases; NASH: non-alcoholic steatohepatitis; NK cell: natural killer cell; PDGFR $\beta$ : plateletderived growth factor receptor- $\beta$; PF: portal fibroblasts; PGE2: prostaglandin E2; PNALT: persistent normal alanine aminotransferase; SDF-1: stromal cell-derived factor-1; SVR: sustained virologic response; TAF: tumor associated fibroblasts; TCGA: the Cancer Genome Atlas; TIMP: tissue inhibitors of metalloproteinase; Wt-1: Wilms tumor-1.

\section{Author contributions}

All authors contributed substantially to the concept, design and writing of the final manuscript.

\section{ACKNOWLEDGMENTS}

Not applicable.

\section{CONFLICTS OF INTEREST}

The authors declare that they have no conflicts of interest.

\section{FUNDING}

No funding or grant or compensation has been received for review.

\section{REFERENCES}

1. GLOBOCAN 2012: Liver cancer: Estimated Cancer Incidence, Mortality and Prevalence Worldwide in 2012. https://publications.iarc.fr/Databases/Iarc-Cancerbases/ GLOBOCAN-2012-Estimated-Cancer-Incidence-MortalityAnd-Prevalence-Worldwide-In-2012-V1.0-2012.

2. Mittal S, El-Serag HB. Epidemiology of HCC: Consider the Population. J Clin Gastroenterol. 2013; 47:S2-S6. https:// doi.org/10.1097/MCG.0b013e3182872f29. [ [PubMed]

3. Parkin DM. The global health burden of infectionassociated cancers in the year 2002. Int J Cancer. 2006; 118:3030-44. https://doi.org/10.1002/ijc.21731. [PubMed]

4. Hernandez-Gea V, Friedman SL. Pathogenesis of liver fibrosis. Annu Rev Pathol. 2011; 6:425-56. https://doi. org/10.1146/annurev-pathol-011110-130246. [PubMed]

5. El-Serag HB. Hepatocellular Carcinoma. N Engl J Med. 2011; 365:1118-27. https://doi.org/10.1056/NEJMra1001683. [PubMed]
6. Affo S, Yu LX, Schwabe RF. The Role of CancerAssociated Fibroblasts and Fibrosis in Liver Cancer. Annu Rev Pathol. 2017; 12:153-86. https://doi.org/10.1146/ annurev-pathol-052016-100322. [

7. Jung YK, Yim HJ. Reversal of liver cirrhosis: current evidence and expectations. Korean J Intern Med. 2017; 32:213-28. https://doi.org/10.3904/kjim.2016.268. [PubMed]

8. Marcellin P, Gane E, Buti M, Afdhal N, Sievert W, Jacobson IM, Washington MK, Germanidis G, Flaherty JF, Aguilar Schall R, Bornstein JD, Kitrinos KM, Subramanian GM, et al. Regression of cirrhosis during treatment with tenofovir disoproxil fumarate for chronic hepatitis B: a 5-year openlabel follow-up study. Lancet. 2013; 381:468-75. https:// doi.org/10.1016/S0140-6736(12)61425-1. [PubMed]

9. D'Ambrosio R, Aghemo A, Rumi MG, Ronchi G, Donato MF, Paradis V, Colombo M, Bedossa P. A morphometric and immunohistochemical study to assess the benefit of a sustained virological response in hepatitis $\mathrm{C}$ virus patients with cirrhosis. Hepatology. 2012; 56:532-43. https://doi. org/10.1002/hep.25606. [PubMed]

10. Li DK, Chung RT. Impact of hepatitis $\mathrm{C}$ virus eradication on hepatocellular carcinogenesis. Cancer. 2015; 121:2874-82. https://doi.org/10.1002/cncr.29528. [PubMed]

11. Papatheodoridis GV, Chan HL, Hansen BE, Janssen HLA, Lampertico P. Risk of hepatocellular carcinoma in chronic hepatitis B: Assessment and modification with current antiviral therapy. J Hepatol. 2015; 62:956-67. https://doi. org/10.1016/i.jhep.2015.01.002. [PubMed]

12. Duarte S, Baber J, Fujii T, Coito AJ. Matrix metalloproteinases in liver injury, repair and fibrosis. Matrix Biol. 2015; 44-46:147-56. https://doi.org/10.1016/j. matbio.2015.01.004. [PubMed]

13. Hemmann S, Graf J, Roderfeld M, Roeb E. Expression of MMPs and TIMPs in liver fibrosis - a systematic review with special emphasis on anti-fibrotic strategies. J Hepatol. 2007; 46:955-75. https://doi.org/10.1016/j. jhep.2007.02.003. [PubMed]

14. Kisseleva T, Cong M, Paik Y, Scholten D, Jiang C, Benner C, Iwaisako K, Moore-Morris T, Scott B, Tsukamoto H, Evans SM, Dillmann W, Glass CK, et al. Myofibroblasts revert to an inactive phenotype during regression of liver fibrosis. Proc Natl Acad Sci U S A. 2012; 109:9448-53. https://doi.org/10.1073/pnas.1201840109. [PubMed]

15. Kisseleva T. The Origin of Fibrogenic Myofibroblasts in Fibrotic Liver. Hepatology. 2017; 65:1039-43. https://doi. org/10.1002/hep.28948. [PubMed]

16. Wake K. "Sternzellen" in the liver: Perisinusoidal cells with special reference to storage of vitamin A. Am J Anat. 1971; 132:429-61. https://doi.org/10.1002/aja.1001320404. [PubMed]

17. Mederacke I, Dapito DH, Affo S, Uchinami H, Schwabe RF. High-yield and high-purity isolation of hepatic stellate cells from normal and fibrotic mouse livers. Nat Protoc. 2015; 10:305-15. https://doi.org/10.1038/nprot.2015.017. [PubMed] 
18. Tsuchida T, Friedman SL. Mechanisms of hepatic stellate cell activation. Nat Rev Gastroenterol Hepatol. 2017; 14:397411. https://doi.org/10.1038/nrgastro.2017.38. [PubMed]

19. Zhang CY, Yuan WG, He P, Lei JH, Wang CX. Liver fibrosis and hepatic stellate cells: Etiology, pathological hallmarks and therapeutic targets. World J Gastroenterol. 2016; 22:10512-22. https://doi.org/10.3748/wjg.v22.i48.10512. [PubMed]

20. Iwaisako K, Jiang C, Zhang M, Cong M, Moore-Morris TJ, Park TJ, Liu X, Xu J, Wang P, Paik YH, Meng F, Asagiri M, Murray LA, et al. Origin of myofibroblasts in the fibrotic liver in mice. Proc Natl Acad Sci U S A. 2014; 111:E3297-305. https://doi.org/10.1073/pnas.1400062111. [PubMed]

21. Mederacke I, Hsu CC, Troeger JS, Huebener P, Mu X, Dapito DH, Pradere JP, Schwabe RF. Fate tracing reveals hepatic stellate cells as dominant contributors to liver fibrosis independent of its aetiology. Nat Commun. 2013; 4:2823. https://doi.org/10.1038/ncomms3823. [PubMed]

22. Zhou Y, Ren H, Dai B, Li J, Shang L, Huang J, Shi X. Hepatocellular carcinoma-derived exosomal miRNA-21 contributes to tumor progression by converting hepatocyte stellate cells to cancer-associated fibroblasts. J Exp Clin Cancer Res. 2018; 37:324. https://doi.org/10.1186/s13046018-0965-2. [PubMed]

23. Zou B, Liu X, Gong Y, Cai C, Li P, Xing S, Pokhrel B, Zhang B, Li J. A novel 12-marker panel of cancer-associated fibroblasts involved in progression of hepatocellular carcinoma. Cancer Manag Res. 2018; 10:5303-11. https:// doi.org/10.2147/CMAR.S176152. [PubMed]

24. Fausther M, Goree JR, Lavoie EG, Graham AL, Sevigny J, Dranoff JA. Establishment and characterization of rat portal myofibroblast cell lines. PLoS One. 2015; 10:e121161. https://doi.org/10.1371/journal.pone.0121161. [PubMed]

25. Kalluri R, Weinberg RA. The basics of epithelialmesenchymal transition. J Clin Invest. 2009; 119:1420-8. https://doi.org/10.1172/JCI39104. [PubMed]

26. Huber MA, Kraut N, Beug H. Molecular requirements for epithelial-mesenchymal transition during tumor progression. Curr Opin Cell Biol. 2005; 17:548-58. https:// doi.org/10.1016/j.ceb.2005.08.001. [PubMed]

27. Iwano M, Plieth D, Danoff TM, Xue C, Okada H, Neilson EG. Evidence that fibroblasts derive from epithelium during tissue fibrosis. J Clin Invest. 2002; 110:341-50. https://doi. org/10.1172/JCI0215518. [PubMed]

28. Zeisberg M, Yang C, Martino M, Duncan MB, Rieder F, Tanjore H, Kalluri R. Fibroblasts derive from hepatocytes in liver fibrosis via epithelial to mesenchymal transition. J Biol Chem. 2007; 282:23337-47. https://doi.org/10.1074/ jbc.M700194200. [PubMed]

29. Wells RG. Epithelial to Mesenchymal Transition in Liver Fibrosis: Here Today, Gone Tomorrow? Hepatology. 2010; 51:737-40. https://doi.org/10.1002/hep.23529. [PubMed]

30. Taura K, Miura K, Iwaisako K, Österreicher CH, Kodama Y, Penz-Osterreicher M, Brenner DA. Hepatocytes do not undergo epithelial-mesenchymal transition in liver fibrosis in mice. Hepatology. 2010; 51:1027-36. https://doi. org/10.1002/hep.23368. [PubMed]
31. Scholten D, Österreicher CH, Scholten A, Iwaisako K, Gu G, Brenner DA, Kisseleva T. Genetic labeling does not detect epithelial-to-mesenchymal transition (EMT) of cholangiocytes in liver fibrosis in mice. Gastroenterology. 2010; 139:987-98. https://doi.org/10.1053/j.gastro.2010.05.005. [PubMed]

32. Zou B, Liu X, Zhang B, Gong Y, Cai C, Li P, Chen J, Xing S, Chen J, Peng S, Pokhrel B, Ding L, Zeng L, et al. The Expression of FAP in Hepatocellular Carcinoma Cells is Induced by Hypoxia and Correlates with Poor Clinical Outcomes. J Cancer. 2018; 9:3278-86. https://doi. org/10.7150/jca.25775. [PubMed]

33. Morén A, Bellomo C, Tsubakihara Y, Kardassis D, Mikulits W, Heldin CH, Moustakas A. LXR $\alpha$ limits TGF $\beta$ dependent hepatocellular carcinoma associated fibroblast differentiation. Oncogenesis. 2019; 8:36. https://doi. org/10.1038/s41389-019-0140-4. [PubMed]

34. Nobili V, Carpino G, Alisi A, Franchitto A, Alpini G, De Vito R, Onori P, Alvaro D, Gaudio E. Hepatic progenitor cells activation, fibrosis, and adipokines production in pediatric nonalcoholic fatty liver disease. Hepatology. 2012; 56:214253. https://doi.org/10.1002/hep.25742. [PubMed]

35. Sekiya S, Miura S, Matsuda-Ito K, Suzuki A. Myofibroblasts Derived from Hepatic Progenitor Cells Create the Tumor Microenvironment. Stem Cell Reports. 2016; 7:1130-1139. https://doi.org/10.1016/j.stemcr.2016.11.002. [PubMed]

36. Xu J, Cong M, Park TJ, Scholten D, Brenner DA, Kisseleva T. Contribution of bone marrow-derived fibrocytes to liver fibrosis. Hepatobiliary Surgery and Nutrition. 2015; 4:34- 47. https://doi.org/10.3978/j.issn.2304-3881.2015.01.01. [PubMed]

37. Quan TE, Bucala R. Culture and analysis of circulating fibrocytes. Methods Mol Med. 2007; 135:423-34. https:// doi.org/10.1007/978-1-59745-401-8_28. [PubMed]

38. Kisseleva T, Uchinami H, Feirt N, Quintana-Bustamante O, Segovia JC, Schwabe RF, Brenner DA. Bone marrow-derived fibrocytes participate in pathogenesis of liver fibrosis. J Hepatol. 2006; 45:429-38. https://doi.org/10.1016/j.jhep.2006.04.014. [PubMed]

39. Bellini A, Mattoli S. The role of the fibrocyte, a bone marrow-derived mesenchymal progenitor, in reactive and reparative fibroses. Lab Invest. 2007; 87:858-70. https:// doi.org/10.1038/labinvest.3700654. [PubMed]

40. Moeller A, Gilpin SE, Ask K, Cox G, Cook D, Gauldie J, Margetts PJ, Farkas L, Dobranowski J, Boylan C, O'Byrne PM, Strieter RM, Kolb M. Circulating fibrocytes are an indicator of poor prognosis in idiopathic pulmonary fibrosis. Am J Respir Crit Care Med. 2009; 179:588-94. https://doi.org/10.1164/rccm.200810-15340C. [PubMed]

41. Gomperts BN, Strieter RM. Fibrocytes in lung disease. J Leukoc Biol. 2007; 82:449-56. https://doi.org/10.1189/ ilb.0906587. [PubMed]

42. Lua I, Asahina K. The Role of Mesothelial Cells in Liver Development, Injury, and Regeneration. Gut and Liver. 2016; 10:166-76. https://doi.org/10.5009/gnl15226. [PubMed]

43. Ijpenberg A, Perez-Pomares JM, Guadix JA, Carmona R, Portillo-Sanchez V, Macias D, Hohenstein P, Miles CM, Hastie ND, Munoz-Chapuli R. Wt1 and retinoic acid 
signaling are essential for stellate cell development and liver morphogenesis. Dev Biol. 2007; 312:157-70. https:// doi.org/10.1016/j.ydbio.2007.09.014. [PubMed]

44. Li Y, Wang J, Asahina K. Mesothelial cells give rise to hepatic stellate cells and myofibroblasts via mesothelialmesenchymal transition in liver injury. Proc Natl Acad Sci U S A. 2013; 110:2324-9. https://doi.org/10.1073/ pnas.1214136110. [ [PubMed]

45. Lua I, Li Y, Zagory JA, Wang KS, French SW, Sevigny J, Asahina K. Characterization of hepatic stellate cells, portal fibroblasts, and mesothelial cells in normal and fibrotic livers. J Hepatol. 2016; 64:1137-46. https://doi. org/10.1016/j.jhep.2016.01.010. [PubMed]

46. Ogawa T, Li Y, Lua I, Hartner A, Asahina K. Isolation of A Unique Hepatic Stellate Cell Population Expressing Integrin alpha8 from Embryonic Mouse Livers. Dev Dyn. 2018; 247:867-881. https://doi.org/10.1002/dvdy.24634. [PubMed]

47. Xu R, Zhang Z, Wang FS. Liver fibrosis: mechanisms of immune-mediated liver injury. Cell Mol Immunol. 2012; 9:296-301. https://doi.org/10.1038/cmi.2011.53. [PubMed]

48. Lindenbach BD, Rice CM. Unravelling hepatitis C virus replication from genome to function. Nature. 2005; 436:9338. https://doi.org/10.1038/nature04077. [PubMed]

49. Schuppan D, Krebs A, Bauer M, Hahn EG. Hepatitis C and liver fibrosis. Cell Death Differ. 2003; 10:S59-67. https:// doi.org/10.1038/sj.cdd.4401163. [PubMed]

50. Tanaka E, Kiyosawa K, Matsumoto A, Kashiwakuma T, Hasegawa A, Mori H, Yanagihara O, Ohta Y. Serum levels of hepatitis $\mathrm{C}$ virus core protein in patients with chronic hepatitis C treated with interferon alfa. Hepatology. 1996; 23:1330-3. https://doi.org/10.1002/hep.510230606. [PubMed]

51. Bataller R, Paik YH, Lindquist JN, Lemasters JJ, Brenner DA. Hepatitis C virus core and nonstructural proteins induce fibrogenic effects in hepatic stellate cells. Gastroenterology. 2004; 126:529-40. https://doi. org/10.1053/j.gastro.2003.11.018. [PubMed]

52. Mazzocca A, Sciammetta SC, Carloni V, Cosmi L, Annunziato F, Harada T, Abrignani S, Pinzani M. Binding of hepatitis $\mathrm{C}$ virus envelope protein E2 to CD81 upregulates matrix metalloproteinase- 2 in human hepatic stellate cells. J Biol Chem. 2005; 280:11329-39. https:// doi.org/10.1074/jbc.M410161200. [PubMed]

53. Granato M, Zompetta C, Vescarelli E, Rizzello C, Cardi A, Valia S, Antonelli G, Marchese C, Torrisi MR, Faggioni A, Cirone M. HCV derived from sera of $\mathrm{HCV}$-infected patients induces pro-fibrotic effects in human primary fibroblasts by activating GLI2. Sci Rep. 2016; 6:30649. https://doi. org/10.1038/srep30649. [PubMed]

54. Fabian SL, Penchev RR, St-Jacques B, Rao AN, Sipila P, West KA, McMahon AP, Humphreys BD. HedgehogGli pathway activation during kidney fibrosis. Am J Pathol. 2012; 180:1441-53. https://doi.org/10.1016/j. ajpath.2011.12.039. [PubMed]
55. Buchholz M, Kestler HA, Holzmann K, Ellenrieder V, Schneiderhan W, Siech M, Adler G, Bachem MG, Gress TM. Transcriptome analysis of human hepatic and pancreatic stellate cells: organ-specific variations of a common transcriptional phenotype. J Mol Med (Berl). 2005; 83:795805. https://doi.org/10.1007/s00109-005-0680-2. [PubMed]

56. Nunnari G, Vancheri C, Gilli E, Migliore S, Palermo F, La Rosa C, Nicotra P, Russo R, Cacopardo B. Circulating fibrocytes as a marker of liver fibrosis in chronic hepatitis C. Front Biosci (Elite Ed). 2010; 2:1241-1245. https://doi. org/10.2741/e184. [ubMed]

57. Saha B, Kodys K, Adejumo A, Szabo G. Circulating and Exosome-Packaged Hepatitis C Single-Stranded RNA Induce Monocyte Differentiation via TLR7/8 to Polarized Macrophages and Fibrocytes. J Immunol. 2017; 198:197484. https://doi.org/10.4049/jimmunol.1600797. [PubMed]

58. Chisari FV, Ferrari C. Hepatitis B Virus Immunopathogenesis. Annu Rev Immunol. 1995; 13:29-60. https://doi.org/10.1146/ annurev.iy.13.040195.000333. [PubMed]

59. Bai Q, An J, Wu X, You H, Ma H, Liu T, Gao N, Jia J. HBV promotes the proliferation of hepatic stellate cells via the PDGF-B/PDGFR-beta signaling pathway in vitro. Int J Mol Med. 2012; 30:1443-50. https://doi.org/10.3892/ ijmm.2012.1148. [PubMed]

60. Guo GH, Tan DM, Zhu PA, Liu F. Hepatitis B virus X protein promotes proliferation and upregulates TGFbeta1 and CTGF in human hepatic stellate cell line, LX-2. Hepatobiliary Pancreat Dis Int. 2009; 8:59-64. [PubMed]

61. Zan Y, Zhang Y, Tien P. Hepatitis B virus e antigen induces activation of rat hepatic stellate cells. Biochem Biophys Res Commun. 2013; 435:391-6. https://doi.org/10.1016/j. bbrc.2013.04.098. [PubMed]

62. Hosseini SY, Baesi K, Azarpira N, Pakneiat A, Hosseini SA. The evaluation of fibrotic effects of the hepatitis $B$ virus pre-core in hepatic stellate cells. Biomed Rep. 2017; 6:6714. https://doi.org/10.3892/br.2017.894. [PubMed]

63. Guillot A, Tacke F. Liver Macrophages: Old Dogmas and New Insights. Hepatol Commun. 2019; 3:730-43. https:// doi.org/10.1002/hep4.1356. [PubMed]

64. Gordon S, Pluddemann A. Tissue macrophages: heterogeneity and functions. BMC Biol. 2017; 15:53. https://doi.org/10.1186/s12915-017-0392-4. [PubMed]

65. Karlmark KR, Weiskirchen R, Zimmermann HW, Gassler N, Ginhoux F, Weber C, Merad M, Luedde T, Trautwein C, Tacke F. Hepatic recruitment of the inflammatory Gr1+ monocyte subset upon liver injury promotes hepatic fibrosis. Hepatology. 2009; 50:261-74. https://doi. org/10.1002/hep.22950. [PubMed]

66. Barnes MA, McMullen MR, Roychowdhury S, Madhun NZ, Niese K, Olman MA, Stavitsky AB, Bucala R, Nagy LE. Macrophage migration inhibitory factor is required for recruitment of scar-associated macrophages during liver fibrosis. J Leukoc Biol. 2015; 97:161-9. https://doi. org/10.1189/j1b.3A0614-280R. [PubMed] 
67. Ramachandran P, Pellicoro A, Vernon MA, Boulter L, Aucott RL, Ali A, Hartland SN, Snowdon VK, Cappon A, Gordon-Walker TT, Williams MJ, Dunbar DR, Manning JR, et al. Differential Ly-6C expression identifies the recruited macrophage phenotype, which orchestrates the regression of murine liver fibrosis. Proc Natl Acad Sci U S A. 2012; 109:E3186-95. https://doi. org/10.1073/pnas.1119964109. [PubMed]

68. Duffield JS, Forbes SJ, Constandinou CM, Clay S, Partolina M, Vuthoori S, Wu S, Lang R, Iredale JP. Selective depletion of macrophages reveals distinct, opposing roles during liver injury and repair. J Clin Invest. 2005; 115:5665. https://doi.org/10.1172/JCI200522675. [PubMed]

69. Lavin Y, Winter D, Blecher-Gonen R, David E, KerenShaul H, Merad M, Jung S, Amit I. Tissue-Resident Macrophage Enhancer Landscapes Are Shaped by the Local Microenvironment. Cell. 2014; 159:1312-26. https://doi. org/10.1016/j.cell.2014.11.018. [PubMed]

70. Li H, You H, Fan X, Jia J. Hepatic macrophages in liver fibrosis: pathogenesis and potential therapeutic targets. BMJ Open Gastroenterol. 2016; 3:e000079. https://doi. org/10.1136/bmigast-2016-000079. [PubMed]

71. Zhou X, Yang XF. Progress of targeting transforming growth factor-beta1 small interfering RNA in liver fibrosis. Chin Med Sci J. 2014; 29:231-5. https://doi.org/10.1016/ S1001-9294(14)60076-6. [PubMed]

72. Choi HS, Kang JW, Lee SM. Melatonin attenuates carbon tetrachloride-induced liver fibrosis via inhibition of necroptosis. Transl Res. 2015; 166:292-303. https://doi. org/10.1016/j.trsl.2015.04.002. [PubMed]

73. Karlmark KR, Zimmermann HW, Roderburg C, Gassler N, Wasmuth HE, Luedde T, Trautwein C, Tacke F. The fractalkine receptor $\mathrm{CX}(3) \mathrm{CR} 1$ protects against liver fibrosis by controlling differentiation and survival of infiltrating hepatic monocytes. Hepatology. 2010; 52:176982. https://doi.org/10.1002/hep.23894. [PubMed]

74. Poisson J, Lemoinne S, Boulanger C, Durand F, Moreau R, Valla D, Rautou PE. Liver sinusoidal endothelial cells: Physiology and role in liver diseases. J Hepatol. 2017; 66:21227. https://doi.org/10.1016/j.jhep.2016.07.009. [PubMed]

75. Amicone L, Marchetti A. Microenvironment and tumor cells: two targets for new molecular therapies of hepatocellular carcinoma. Transl Gastroenterol Hepatol. 2018; 3:24. https:// doi.org/10.21037/tgh.2018.04.05. [PubMed]

76. Ju MJ, Qiu SJ, Fan J, Xiao YS, Gao Q, Zhou J, Li YW, Tang ZY. Peritumoral activated hepatic stellate cells predict poor clinical outcome in hepatocellular carcinoma after curative resection. Am J Clin Pathol. 2009; 131:498-510. https://doi. org/10.1309/AJCP86PPBNGOHNNL. [PubMed]

77. Gascard P, Tlsty TD. Carcinoma-associated fibroblasts: orchestrating the composition of malignancy. Genes Dev. 2016; 30:1002-19. https://doi.org/10.1101/gad.279737.116. [PubMed]

78. Zhao W, Zhang L, Yin Z, Su W, Ren G, Zhou C, You J, Fan J, Wang X. Activated hepatic stellate cells promote hepatocellular carcinoma development in immunocompetent mice. Int J Cancer. 2011; 129:2651-61. https://doi. org/10.1002/ijc.25920. [PubMed]

79. Zhao W, Zhang L, Xu Y, Zhang Z, Ren G, Tang K, Kuang P, Zhao B, Yin Z, Wang X. Hepatic stellate cells promote tumor progression by enhancement of immunosuppressive cells in an orthotopic liver tumor mouse model. Lab Invest. 2014; 94:18291. https://doi.org/10.1038/labinvest.2013.139. [PubMed]

80. Deng Y, Cheng J, Fu B, Liu W, Chen G, Zhang Q, Yang Y. Hepatic carcinoma-associated fibroblasts enhance immune suppression by facilitating the generation of myeloidderived suppressor cells. Oncogene. 2016; 36:1090-1101. https://doi.org/10.1038/onc.2016.273. [PubMed]

81. Han Y, Chen Z, Yang Y, Jiang Z, Gu Y, Liu Y, Lin C, Pan Z, Yu Y, Jiang M, Zhou W, Cao X. Human CD14+ CTLA$4+$ regulatory dendritic cells suppress T-cell response by cytotoxic T-lymphocyte antigen-4-dependent IL-10 and indoleamine-2,3-dioxygenase production in hepatocellular carcinoma. Hepatology. 2014; 59:567-79. https://doi. org/10.1002/hep.26694. [PubMed]

82. Cheng JT, Deng YN, Yi HM, Wang GY, Fu BS, Chen WJ, Liu W, Tai Y, Peng YW, Zhang Q. Hepatic carcinomaassociated fibroblasts induce IDO-producing regulatory dendritic cells through IL-6-mediated STAT3 activation. Oncogenesis. 2016; 5:e198. https://doi.org/10.1038/ oncsis.2016.7. [PubMed]

83. Li T, Yang Y, Hua X, Wang G, Liu W, Jia C, Tai Y, Zhang Q, Chen G. Hepatocellular carcinoma-associated fibroblasts trigger NK cell dysfunction via PGE2 and IDO. Cancer Lett. 2012; 318:154-61. https://doi.org/10.1016/j. canlet.2011.12.020. [PubMed]

84. Xu Y, Zhao W, Xu J, Li J, Hong Z, Yin Z, Wang X. Activated hepatic stellate cells promote liver cancer by induction of myeloid-derived suppressor cells through cyclooxygenase-2. Oncotarget. 2016; 7:8866-78. https:// doi.org/10.18632/oncotarget.6839. [PubMed]

85. Hochhaus A, Larson RA, Guilhot F, Radich JP, Branford $\mathrm{S}$, Hughes TP, Baccarani M, Deininger MW, Cervantes F, Fujihara S, Ortmann CE, Menssen HD, Kantarjian H, et al. Long-Term Outcomes of Imatinib Treatment for Chronic Myeloid Leukemia. N Engl J Med. 2017; 376:917-27. https://doi.org/10.1056/NEJMoa1609324. [PubMed]

86. Thompson AI, Conroy KP, Henderson NC. Hepatic stellate cells: central modulators of hepatic carcinogenesis. BMC Gastroenterol. 2015; 15:63. https://doi.org/10.1186/s12876015-0291-5. [PubMed]

87. Chen W, Wu J, Shi H, Wang Z, Zhang G, Cao Y, Jiang C, Ding Y. Hepatic Stellate Cell Coculture Enables Sorafenib Resistance in Huh7 Cells through HGF/c-Met/Akt and Jak2/ Stat3 Pathways. BioMed Research International. 2014; 2014:764981. https://doi.org/10.1155/2014/764981. [PubMed]

88. Azzariti A, Mancarella S, Porcelli L, Quatrale AE, Caligiuri A, Lupo L, Dituri F, Giannelli G. Hepatic stellate cells induce hepatocellular carcinoma cell resistance to sorafenib 
through the laminin-332/alpha3 integrin axis recovery of focal adhesion kinase ubiquitination. Hepatology. 2016; 64:2103-17. https://doi.org/10.1002/hep.28835. [PubMed]

89. Song Y, Kim SH, Kim KM, Choi EK, Kim J, Seo HR. Activated hepatic stellate cells play pivotal roles in hepatocellular carcinoma cell chemoresistance and migration in multicellular tumor spheroids. Sci Rep. 2016; 6:36750. https://doi.org/10.1038/srep36750. [PubMed]

90. Ozdemir BC, Pentcheva-Hoang T, Carstens JL, Zheng X, Wu CC, Simpson TR, Laklai H, Sugimoto H, Kahlert C, Novitskiy SV, De Jesus-Acosta A, Sharma P, Heidari P, et al. Depletion of carcinoma-associated fibroblasts and fibrosis induces immunosuppression and accelerates pancreas cancer with reduced survival. Cancer Cell. 2014; 25:719-34. https://doi.org/10.1016/j.ccr.2014.04.005. [PubMed]

91. Mogler C, König C, Wieland M, Runge A, Besemfelder E, Komljenovic D, Longerich T, Schirmacher P, Augustin HG. Hepatic stellate cells limit hepatocellular carcinoma progression through the orphan receptor endosialin. EMBO Mol Med. 2017; 9:741-9. https://doi.org/10.15252/ emmm.201607222. [ [PubMed]

92. Saffroy R, Pham P, Reffas M, Takka M, Lemoine A, Debuire B. New perspectives and strategy research biomarkers for hepatocellular carcinoma. Clin Chem Lab Med. 2007; 45:116979. https://doi.org/10.1515/CCLM.2007.262. [PubMed]

93. Chauhan R, Lahiri N. Tissue- and Serum-Associated Biomarkers of Hepatocellular Carcinoma. Biomark Cancer. 2016; 8:37-55. https://doi.org/10.4137/BIC.S34413. [PubMed]

94. Lou J, Zhang L, Lv S, Zhang C, Jiang S. Biomarkers for Hepatocellular Carcinoma. Biomark Cancer. 2017; 9:1-9. https://doi.org/10.1177/1179299X16684640. [PubMed]

95. Gingold JA, Zhu D, Lee DF, Kaseb A, Chen J. Genomic Profiling and Metabolic Homeostasis in Primary Liver Cancers. Trends Mol Med. 2018; 24:395-411. https://doi. org/10.1016/j.molmed.2018.02.006. [PubMed]

96. Brechot C, Gozuacik D, Murakami Y, Paterlini-Brechot P. Molecular bases for the development of hepatitis B virus (HBV)-related hepatocellular carcinoma (HCC). Semin Cancer Biol. 2000; 10:211-31. https://doi.org/10.1006/ scbi.2000.0321. [PubMed]

97. Paterlini-Brechot P, Saigo K, Murakami Y, Chami M, Gozuacik D, Mugnier C, Lagorce D, Brechot C. Hepatitis $\mathrm{B}$ virus-related insertional mutagenesis occurs frequently in human liver cancers and recurrently targets human telomerase gene. Oncogene. 2003; 22:3911-6. https://doi. org/10.1038/sj.onc.1206492. [PubMed]

98. Bréchot C, Thiers V, Kremsdorf D, Nalpas B, Pol S, Paterlini-Bréchot P. Persistent hepatitis B virus infection in subjects without hepatitis B surface antigen: Clinically significant or purely "occult"? Hepatology. 2001; 34:194 203. https://doi.org/10.1053/jhep.2001.25172. [PubMed]

99. Estevez J, Chen VL, Podlaha O, Li B, Le A, Vutien P, Chang ET, Rosenberg-Hasson Y, Jiang Z, Pflanz S, Ge D, Gaggar A, Nguyen MH. Differential Serum Cytokine
Profiles in Patients with Chronic Hepatitis B, C, and Hepatocellular Carcinoma. Sci Rep. 2017; 7:11867. https:// doi.org/10.1038/s41598-017-11975-7. [PubMed]

100. Hsia CY, Huo TI, Chiang SY, Lu MF, Sun CL, Wu JC, Lee PC, Chi CW, Lui WY, Lee SD. Evaluation of interleukin-6, interleukin-10 and human hepatocyte growth factor as tumor markers for hepatocellular carcinoma. Eur $\mathrm{J}$ Surg Oncol. 2007; 33:208-12. https://doi.org/10.1016/j. ejso.2006.10.036. [PubMed]

101. Fuster D, Tsui JI, Cheng DM, Quinn EK, Armah KA, Nunes D, Freiberg MS, Samet JH. Interleukin-6 is associated with noninvasive markers of liver fibrosis in HIVinfected patients with alcohol problems. AIDS Res Hum Retroviruses. 2013; 29:1110-6. https://doi.org/10.1089/ aid.2012.0348. [PubMed]

102. Sziksz E, Pap D, Lippai R, Beres NJ, Fekete A, Szabo AJ, Vannay A. Fibrosis Related Inflammatory Mediators: Role of the IL-10 Cytokine Family. Mediators Inflamm. 2015; 2015:764641. https://doi.org/10.1155/2015/764641. [PubMed]

103. Mizukoshi E, Kaneko S. Immune cell therapy for hepatocellular carcinoma. J Hematol Oncol. 2019; 12:52. https://doi.org/10.1186/s13045-019-0742-5. [PubMed]

104. Liu T, Xue R, Dong L, Wu H, Zhang D, Shen X. Rapid determination of serological cytokine biomarkers for hepatitis B virus-related hepatocellular carcinoma using antibody microarrays. Acta Biochim Biophys Sin (Shanghai). 2011; 43:45-51. https://doi.org/10.1093/abbs/gmq111. [pubMed]

105. Tang S, Liu Z, Zhang Y, He Y, Pan D, Liu Y, Liu Q, Zhang Z, Yuan Y. Rather than Rs1800796 Polymorphism, Expression of Interleukin-6 is Associated with Disease Progression of Chronic HBV Infection in a Chinese Han Population. Dis Markers. 2013; 35:799-805. https://doi. org/10.1155/2013/508023. [PubMed]

106. Wong VW, Yu J, Cheng AS, Wong GL, Chan HY, Chu ES, Ng EK, Chan FK, Sung JJ, Chan HL. High serum interleukin-6 level predicts future hepatocellular carcinoma development in patients with chronic hepatitis B. Int J Cancer. 2009; 124:2766-70. https://doi.org/10.1002/ijc.24281. [PubMed]

107. Debes JD, van Tilborg M, Groothuismink ZMA, Hansen BE, Schulze zur Wiesch J, von Felden J, de Knegt RJ, Boonstra A. Levels of Cytokines in Serum Associate With Development of Hepatocellular Carcinoma in Patients With HCV Infection Treated With Direct-Acting Antivirals. Gastroenterology. 2018; 154:515-517.e3. https://doi. org/10.1053/j.gastro.2017.10.035. [PubMed]

108. Zekri AN, El Deeb S, Bahnassy AA, Badr AM, Abdellateif MS, Esmat G, Salama H, Mohanad M, El-Dien AE, Rabah S, Abd Elkader A. Role of relevant immune-modulators and cytokines in hepatocellular carcinoma and premalignant hepatic lesions. World J Gastroenterol. 2018; 24:1228-38. https://doi.org/10.3748/wjg.v24.i11.1228. [PubMed]

109. Othman MS, Aref AM, Mohamed AA, Ibrahim WA. Serum Levels of Interleukin-6 and Interleukin-10 as Biomarkers for Hepatocellular Carcinoma in Egyptian 
Patients. ISRN Hepatology. 2013; 2013:412317. https://doi. org/10.1155/2013/412317. [PubMed]

110. Nakagawa H, Maeda S, Yoshida H, Tateishi R, Masuzaki R, Ohki T, Hayakawa Y, Kinoshita H, Yamakado M, Kato N, Shiina S, Omata M. Serum IL-6 levels and the risk for hepatocarcinogenesis in chronic hepatitis C patients: An analysis based on gender differences. Int J Cancer. 2009; 125:2264-9. https://doi.org/10.1002/ijc.24720. [PubMed]

111. Hammad LN, Abdelraouf SM, Hassanein FS, Mohamed WA, Schaalan MF. Circulating IL-6, IL-17 and vitamin D in hepatocellular carcinoma: potential biomarkers for a more favorable prognosis? J Immunotoxicol. 2013; 10:380-6. https://doi.org/10.3109/1547691X.2012.758198. [PubMed]
112. Zekri AR, Alam El-Din HM, Bahnassy AA, Zayed NA, Mohamed WS, El-Masry SH, Gouda SK, Esmat G. Serum levels of soluble Fas, soluble tumor necrosis factorreceptor II, interleukin- 2 receptor and interleukin- 8 as early predictors of hepatocellular carcinoma in Egyptian patients with hepatitis C virus genotype-4. Comp Hepatol. 2010; 9:1. https://doi.org/10.1186/1476-5926-9-1. [PubMed] 